\title{
Digital Citizenship Education: Shaping Digital Ethics in Society 5.0
}

\author{
Endang Wulandari*, Winarno, Triyanto \\ Civic Education Postgraduate Program, Universitas Sebelas Maret, Surakarta, Jawa Tengah, Indonesia
}

Received January 17, 2021; Revised March 31, 2021; Accepted April 22, 2021

\section{Cite This Paper in the following Citation Styles}

(a): [1] Endang Wulandari, Winarno, Triyanto , "Digital Citizenship Education: Shaping Digital Ethics in Society 5.0," Universal Journal of Educational Research, Vol. 9, No. 5, pp. 948 - 956, 2021. DOI: 10.13189/ujer.2021.090507.

(b): Endang Wulandari, Winarno, Triyanto (2021). Digital Citizenship Education: Shaping Digital Ethics in Society 5.0. Universal Journal of Educational Research, 9(5), 948 - 956. DOI: 10.13189/ujer.2021.090507.

Copyright $\mathrm{C} 2021$ by authors, all rights reserved. Authors agree that this article remains permanently open access under the terms of the Creative Commons Attribution License 4.0 International License

\begin{abstract}
The strong current of globalization has driven the rapid development of the digital era and technology so that the term digital citizenship has emerged. The emergence of Society 5.0 era demands a balance between technology and the environment. But on the other hand, the emergence of the Society 5.0 era was not matched by the formation of digital ethics in society. The rise of cybercrime cases such as the spread of fake news (hoaxes), hate speech, and cyberbullying shows the lack of digital ethics in society. The formation of digital ethics is an important thing that must be done, one of which is through digital citizenship education in society. The method used in this research is qualitative with a case study approach. Data collection was carried out through observation and in-depth interviews with several main sources, namely the community board of Kampung Cyber and community members based on purposive sampling and snowball sampling techniques. The results showed that the emergence of the Kampung Cyber community became the main forum for the implementation of digital citizenship education in society, especially in shaping ethics. The application of norms in society becomes the main control for any deviant actions in the use of technology. It takes the development of competencies and digital ethical values that are in accordance with the era of Society 5.0, such as technological literacy, responsibility, honesty, critical thinking, problem solving, creativity, equality and local wisdom. The existence of a key figure as a model in social learning will shape people's behavior according to digital ethical competencies in the era of Society 5.0. In addition, it is necessary to create a good environment and strong ties in society that will encourage the successful formation of
\end{abstract}

ideal and ethical digital citizenship in the era of Society 5.0 .

Keywords Education, Digital Citizenship, Kampung Cyber, Digital Ethics, Community, Society 5.0

\section{Introduction}

The emergency of the 4.0 industrial revolution era has not ended yet. Indonesia was surprised by the emergence of a new concept, namely Society 5.0 which was initiated by the Japanese. The concept of Society 5.0 is not only limited to manufacturing sectors but also solves social problems with the help of the integration of physical and virtual spaces [1]. The concept of Society 5.0 has big data technology collected through the Internet of Things (IoT) converted into Artificial Intelligence (AI) [2] [3], which is something that can help someone to live a better life so that the concept of Society 5.0 will bring big changes to the social order. The main principle in implementing the Society5.0 era is the balance of business development, economy, and the social environment. With technology in the era of Society 5.0, the problems created in the industrial revolution 4.0 (reduced socialization between communities, job opportunities, and the impact of other institutions) will decrease [4]. The era of Society 5.0 demands a balance between technology and society. So the emergence of the Society 5.0 era can be the answer to existing problems.

But in fact Indonesia is still spinning in the era of the industrial revolution 4.0. APJII survey results show that 
from year to year internet users in Indonesia have increased, this year it is up $10.12 \%$ from the previous year. The increase in internet users has reached 27 million. This means that there are 171.17 million internet users out of a total of 246.16 million people in Indonesia [5]. Indonesian citizens have become part of digital citizenship. However, the increasing number of internet users in Indonesia raises the problem of digital crime. Data presented by the Ministry of Communication and Informatics state that there are as many as 800 thousand websites in Indonesia that are indicated to spread hoaxes and hate speech. Apart from hate speech, another criminal act that is often committed is cyberbullying. Data obtained from the police show that there were 225 hate speech crimes recorded in 2018. Meanwhile, in 2019 there were 101 cases of hate speech and defamation, totaling 1,271 cases. Meanwhile, in 2020 there were 657 cases of defamation [6]. These crimes were committed through various social media including Facebook, Instagram, WhatsApp, Path, Twitter, and so on. This shows that there is no balance between technology and the social environment as the principles of Society 5.0. This condition often creates conflicts between technology users. The data above show the increasing abuse of technology for negative things, which is not in accordance with the purpose of creating technology that should provide benefits for life. If this condition is not resolved properly, the same cases will become more prevalent. In addition, the emergence of technology-related problems also raises public concern about using it. This will hamper the digitization process.

The term digital citizenship has been used by Karen Mossberger and Caroline J. Tolbert, in her book entitled Digital Citizenship: The Internet, Society, and Participation, which defines digital citizenship as the ability to participate in online communities [7]. Furthermore, digital citizenship can be defined as those who use technology to obtain political information, help work and improve the economy. So it is not surprising that the term digital citizenship is widely known by the public. Along with the changing times, the term citizenship has also changed. According to Choi, currently digital citizenship is divided into four categories, namely digital citizenship as ethics; media and technology literacy; Participation / Engagement; and critical resistance [8]. First, Digital citizenship as ethics refers to how internet users engage in appropriate, safe, ethical and responsible ways in internetworking activities. Second, digital citizenship as media and technology literacy shows a person's ability to access, use, create, and evaluate information and communicate with other users. Third, Digital citizenship as participation / Engagement introduces different types of online engagement, including political, socio-economic and cultural. Fourth, digital citizenship as a critical resistance, which is related to activeness and encouragement with the aim of participating in virtual communities. So based on these four categories the problems that occur in Indonesia are related to the digital ethics of society in using technology. Where the emergence of various cases of hate speech, hoaxes, bullying is caused by a lack of responsibility from the user.

Digital ethics can be interpreted as a ticket that a person must have to enter a community. In essence, digital ethics is a standard of internet behavior as well as social behavior that applies in the online world [9]. Nor Aslamiah explained communication ethics that can be used in the digital world with the concept of "THINK", namely:

1. Is it True? Is your post correct? or is it just a problem with no clear source?

2. Is It Hurtful? Will your post hurt other people's feelings?

3. Is It Illegal? did your post violate the law?

4. Is it Necessary? are you the most important? posts that are not important will annoy other people.

5. Is it Kind? Be courteous to your posts? make sure the post that is produced does not use words that can be offensive.

So from the explanation above, digital ethics must be applied by every digital citizen. Microsoft in Fostering Digital Citizenship explains the reasons why digital citizenship ethics must be developed, namely: (1) Everyone must learn digital citizenship and develop a sense of ownership and personal responsibility so that they can make good and ethical decisions in the online world; (2) The online world presents many great opportunities for young people, but there are also many risks that must be faced. To minimize these risks, young people must develop a strong sense of digital citizenship; (3) An online security approach that includes digital citizenship will help young people to interact safely in the online world [10]. Therefore, teaching about digital literacy and digital ethics for citizens is something that must be done in order to create healthy and safe interactions on social media.

So that efforts are needed to shape the digital ethics of society in the era of Society 5.0, one of which is through the implementation of digital citizenship education. Education is a conscious effort made in learning activities. Especially in the digital era like today, education is at the forefront of realizing ethical and responsible digital citizenship. Building digital ethics can be done through formal education in schools and education in the community. Synergy is needed between the government and community participation to carry out digital citizenship education in society, one of which is through the civil society. In this case the term civic community relates to individuals as members of society, so that the civic community can be interpreted as a place where forms of local social and economic institutional organizations facilitate a strong social order by building close relationships between citizens through most of the local 
oriented institutions and organizations [11]. So that the community has an important role, one of which is as a forum for implementing digital citizenship education in society to shape ethics.

One community that cares about the development of the digital era is the Kampung Cyber community. The initial goal of establishing Kampung Cyber was to introduce the wider community about technology. In addition, various activities were carried out to introduce computers and the internet to the public. Along with the development of the digital era, Kampung Cyber Yogyakarta has become one of the places for digital education. The era of Society 5.0 is the driving force for this community to implement digital citizenship education in society, especially in the formation of ethics. Therefore this research will focus on discussing digital citizenship education in the Kampung Cyber community, especially in the formation of ethics in the era of Society 5.0.

\section{Materials and Methods}

The research method chosen is a qualitative method with a case study approach. Qualitative research aims to understand social phenomena from the participant's point of view. A case study was chosen because it is a series of scientific activities carried out intensively, in detail and in depth about a program, event, and activity, to obtain in-depth knowledge of events or objects [12]. So you can explore the unique and actual things that exist in the Kampung Cyber community. The research location chosen was the Kampung Cyber community which is located in Kampung Taman I / 434, Patehan, Kraton District, Yogyakarta City. The location was chosen because the Kampung Cyber community is one of the communities that have goals related to the implementation of digital citizenship education in society. This research was conducted for approximately five months. This study uses field observation techniques by interviewing several informants in the Kampung Cyber community. Informants were selected based on purposive sampling and snowball sampling techniques. Interviews were conducted with several pillars of 36 and 36 neighborhood administrators, direct observations were made on community activities and literature studies that discussed digital citizenship education, digital ethics, and digital citizenship. In addition, this study uses literacy study methods as a complement to data. Test the validity of the data used in this study using data triangulation. While the data analysis technique uses qualitative data analysis in the model of Miles and Huberman [12] which consists of three activities, namely data reduction, data presentation, and drawing conclusions. This research was conducted in 6 stages, starting with the identification of problems in the field, determining the focus of the problem, followed by data collection, data processing, emerging theories and ending with research reporting.

\section{Result and Discussion}

The era of Society 5.0 is a new era in human-centered and technology-based social life. This concept was born from the development of the 4.0 industrial revolution which is considered to have the potential to reduce the role of humans. Through Society 5.0, artificial intelligence will transform big data collected via the internet in all areas of life into new wisdom, which will be dedicated to improving human abilities in opening up opportunities for their lives. This is what the Yogyakarta Provincial Government tried to develop in 2006 which launched the Jogja Cyber Province program.

The Jogja Cyber Province program is a form of implementing Electronic Government (e-Government) to encourage the use of technology. Electronic Government (e-Government) is an initiative developed to encourage the widest possible use of information and communication technology for the public and government in order to increase interaction with one another. Jogja Cyber Province is a provincial model that transforms information and knowledge-based community-based services using information and communication technology as an accelerator for provincial development that is competitive, comfortable, independent, efficient, and effective. [13]

However, in this era of Society 5.0, technological developments must be accompanied by digital citizenship education and the formation of digital ethics. Thus, technological developments will provide benefits to human life.

\subsection{Importance of Digital Citizenship Education for the Society}

Society 5.0 has brought the world to a more complex digital era. This of course must be followed by the community in using technology. Likewise in Yogyakarta, the emergence of various technologies has brought changes in the order of life of society. Society must be able to adapt to the presence of technology, and take a role as part of digital citizenship. Digital citizenships are those who use technology to obtain political information, help with jobs and improve the economy. [7]. However, the conditions of the people in Kampung Taman Yogyakarta have not yet supported the formation of ideal digital citizenship. The results of the preliminary research conducted show that the people there can only use the internet carelessly. This means that people do not know how to take advantage of existing internet technology facilities to support their work and their survival. Most of them only use the internet to access social media (WhatsApp, Facebook, Twitter, YouTube, etc.) and entertainment. Some residents admit that when using social media, they view and post videos, 
pictures, other expressions to show their existence and have fun without considering the existence of other users. This often creates conflicts between communities because they are confused over each other's posts.

Seeing this, an awareness emerged from one of the residents, namely Antonius Sasongko (Koko) to apply digital citizenship education to the people of Kampung Taman. It is important to do so because people have the right to understand technology and its use. The rapid development of the digital era and the emergence of Society 5.0 demands that the realm of education adjusts to existing conditions. Education must be done whether in school or in society so that it can keep up with the development of digital era.

So digital citizenship education is important to be implemented at every level of society. Digital citizenship education must be carried out in a sustainable manner, especially for today's young generation, both in schools and in society. Digital citizenship education is education provided to people to understand the elements of digital citizenship. This is what is trying to instill in the people of Kampung Taman, so that they can act as the ideal digital citizenship name. Digital citizenship education initiated by Antonius Sasongko (Koko) is to shape the values, attitudes, knowledge and skills of the people of Kampung Taman. In addition, specifically digital citizenship education in Kampung Taman aims to shape the digital ethics of the community. So to carry out digital citizenship education for the people of Kampung Taman, the Kampung Cyber community was formed. Providing education through the community is considered an effective way to get to know technology and shape digital ethics. Along with the emergence of awareness from the public about the importance of digital citizenship education, the initiative to form a Kampung Cyber community received a good response from the surrounding community. So in 2008 the Kampung Cyber community was formally formed based on the agreement of the local community as a forum for implementing digital citizenship education.

The theoretical formation of Kampung Cyber community can be seen from several perspectives. One of them is the perspective of civil society. The civil society perspective emphasizes the importance to communities to establish close relationships between social, political, economic, religious and other fields of social organization. Most importantly, this perspective emphasizes informal integration and hence, the process of social control in maintaining the stability and welfare of society [14]. So besides being a forum for implementing digital citizenship education, the Kampung Cyber community is also a social control for every action of the Kampung Taman community. The existence of a community in society will have a good impact because there are strong ties between its members to lead to better change. Civil society can be a driver of change and a driving force for the development of an era, including the Society 5.0 era. Like the Kampung
Cyber community as a form of civil society in society, its existence has an important role in the implementation of digital citizenship education, especially in shaping ethics in facing the Society 5.0 era.

\subsection{Digital Citizenship Education in Kampung Cyber Community}

The emergence of Society 5.0 demands a balance between technology and the social environment. Tredinnick, Luke in a book on digital information culture states that the basis for balancing the digital divide includes three units, namely money, time and education [15]. So the importance of digital citizenship education is to achieve a balance between technology and the social environment. Education can be done anywhere and anytime, one of which is through the community. Kampung Cyber Community was originally a program initiated by the Kampung Taman community to introduce technology to the community. However, the program continues to grow so that it becomes a community pioneered by Antonius Sasongko. The emergence of the Kampung Cyber community is one of the solution steps in accelerating information literacy and internet-based technology and shaping the community's digital ethics. Kampung Cyber Community is an ICT-based village that develops an internet network system [16]. Since its inception, the Kampung Cyber community has played a role in the implementation of digital citizenship education in the community. The Kampung Cyber Community encourages the formation of ideal and ethical digital citizenship.

With the advent of the concept of digital citizenship, not many people know how they should take part. Digital citizenship is the ability to participate in online societies [7]. In general, Digital Citizenship has nine main elements that explain the use of technology in the digital age. These elements are digital access, digital commerce, digital communication, digital literacy, digital etiquette, digital law, digital rights and responsibilities, digital health and wellness, and digital security [17]. Digital citizenship education in the Kampung Cyber community is closely related to elements of digital citizenship. Digital citizenship education provides an understanding of nine main elements. In particular, the Kampung Cyber community prioritizes ethical elements. Digital citizenship education in the Kampung Cyber community will instill values, attitudes, knowledge and skills that lead to the formation of digital ethics, especially for the younger generation. Digital ethics is a standard in using digital technology based on applicable norms to be polite [18]. The Digital Ethics category is "safe, responsible, and ethical use of technology and the Internet." [8] A good digital citizen needs to know the norms and / or values regarding the appropriate and effective use of technology and / or the internet, have digital awareness, understand digital rights and responsibilities, so that in surfing and 
using social media politeness is needed, so that values and norms are essential in the successful implementation of digital citizenship education.

The process of digital citizenship education in the Kampung cyber community begins with the existence of norms that become a collective agreement. Based on the results of interviews and observations made, the basic norms in the Kampung Cyber community are togetherness, mutual cooperation and tolerance. Given that the Kampung Taman community has a diversity of religions, education and occupations, these norms teach the basis for carrying out every activity in the Kampung Cyber community. The existence of values and norms in the Kampung Cyber community becomes a guideline for social correction when community members commit deviant actions through social media. Like social deviations in the real world, deviant behavior carried out on social media is also subject to sanctions based on prevailing values and norms. The existence of values and norms that apply in the use of social media has made the community managing Kampung Taman to be more careful in using social media. Several things related to the use of social media can be controlled by the existence of social values and norms, such as the use of dirty words, hate speech, the spread of fake news and others. As long as the behavior can be seen by group members, the realm of values and norms also applies. Efforts to protect each other become a bulwark so as not to fall into the use of technology for negative things. But the problem returns to individuals, when individuals misunderstand their actions on social media and society considers them to violate prevailing values and norms. For the people of Kampung Taman, this issue is seen as part of a culture that takes time to adjust. Here the role of tolerance norms is the controller.

In addition to being guided by the values and norms that apply in society, in implementing digital citizenship education, the Kampung Cyber community also develops basic competencies in shaping digital ethics. This is the second step so that digital citizenship education can run effectively. According to Antonius Sasongko (Koko), the development of basic competencies is important to be carried out in accordance with the conditions of the community so that the final goal can be achieved. The development of this competency will later become the basis for forming an ethical personality in using digital technology. This development is carried out by the core board and representatives of the members of the Kampung Cyber community.

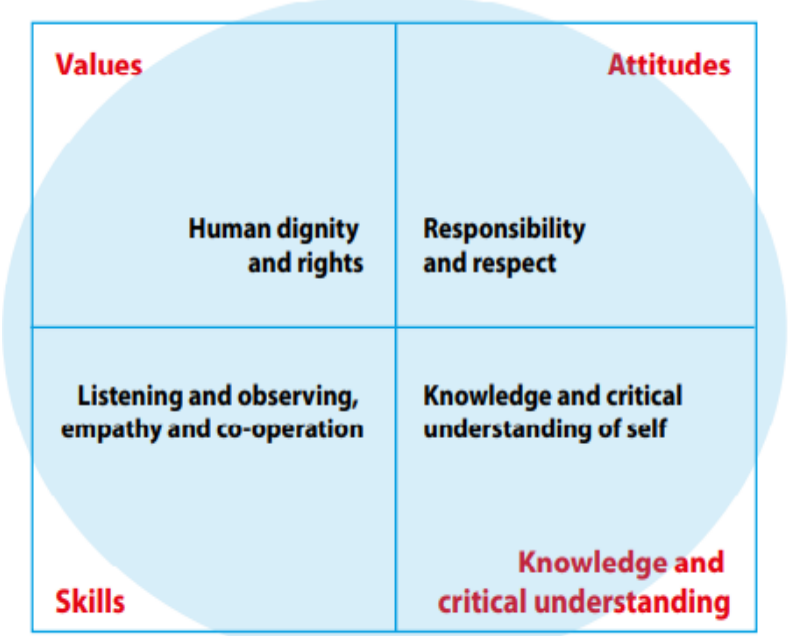

Figure 1. Ethics - Core digital citizenship competences

The picture above shows the basic competencies developed in digital citizenship education in the Kampung Cyber community, particularly in shaping ethics. The emergence of the concept of Society 5.0 is the basis for the development of the above competencies. Where in the era of Society 5.0, it made everyone inevitably have to master the existing basic competencies in order to be ready to face them. So that the community must play an active role in activities, that encourage the formation of these competencies. George Hebert Mest in Santoso mentions this role as internalization, which results in dynamic socialization because individual personalities will be shaped by people who experience changes in form and are expressed by the individual in the form of everyday individual behavior [19]. In other words, the more often a person participates in activities in the Kampung Cyber community, the greater the success in shaping one's digital ethics. This is because the internalization process that a person continues to accept will form a personality according to the instilled competence.

In order for the formation of digital ethics to run effectively, the Kampung Cyber community explained in detail the basic material and values taught. The materials and values are arranged based on the competencies to be achieved, the needs of the community and the prevailing norms. This is so that the materials and values provided can be accepted by the community and implemented in everyday life. 
Table 1. Basic materials and value in digital citizenship education in Kampung Cyber community

\begin{tabular}{|c|l|}
\hline Material & \multicolumn{1}{c|}{ Description } \\
\hline $\begin{array}{c}\text { Technology } \\
\text { Literacy }\end{array}$ & $\begin{array}{l}\text { Technological literacy means that members of } \\
\text { society must be able to use existing technology. }\end{array}$ \\
\hline Responsibility & $\begin{array}{l}\text { The responsibility in question is to form social } \\
\text { media and technology users who comply with the } \\
\text { prevailing rules or norms. }\end{array}$ \\
\hline Honest & $\begin{array}{l}\text { Honest what is meant is that members of the } \\
\text { public can confirm the truth of the news that is } \\
\text { spread. }\end{array}$ \\
\hline $\begin{array}{c}\text { Critical } \\
\text { thinking }\end{array}$ & $\begin{array}{l}\text { Critical thinking is meant to be critical of the news } \\
\text { received by ensuring its truth and being able to } \\
\text { solve the problems faced. }\end{array}$ \\
\hline $\begin{array}{c}\text { Problem } \\
\text { Solving }\end{array}$ & $\begin{array}{l}\text { Teaching individuals to solve problems that exist } \\
\text { in the use of technology following norms }\end{array}$ \\
\hline Creativity & $\begin{array}{l}\text { The creativity in question is the freedom to create } \\
\text { new things with existing technology by the } \\
\text { prevailing norms. }\end{array}$ \\
\hline Equality & $\begin{array}{l}\text { Equality teaches that every individual has the } \\
\text { same rights and position in using technology }\end{array}$ \\
\hline Local wisdom & $\begin{array}{l}\text { Utilizing local wisdom values as a media and } \\
\text { material in shaping digital ethics }\end{array}$ \\
\hline
\end{tabular}

The table above is the basic material and values in digital citizenship education in Kampung Cyber in shaping digital ethics. The First is technological literacy. The technological literacy is an ability that must be possessed, especially in the era of Society 5.0 which prioritizes people who understand technology. So that the Kampung Cyber community provides learning to community members about various technologies that can be used in everyday life, such as online marketing, technology for designing and so on. The condition of people who do not know technology becomes an obstacle in realizing Society 5.0, so that technological literacy is the basic material given. Technological literacy will encourage people to be able to follow technological developments that occur. As one resident said, this technological literacy has provided great benefits so that people can now use existing technology in their daily activities that encourage a better life. This technological literacy is carried out by holding trainings and workshops that are attended by all citizens, especially the younger generation. According to local residents, technology literacy training is given every two months by introducing new applications. So that this will form the digital skills of the community According to local residents, technology literacy training is given every two months by introducing new applications. So that this will form the digital skills of the community According to local residents, technology literacy training is given every two months by introducing new applications. So that this will forms the digital skills of the community.

The second is responsibility. The implementation of digital citizenship education in Kampung Cyber also fosters a responsible attitude towards community members, such as formed technology users who obey the applicable rules or norms. Digital citizenship education is taught to build public awareness to use the technology provided in the Kampung Cyber community for positive things and to be responsible for any news or information they spread. The responsibility that is formed is not only for the existing community members but here is also related to the responsibility of the Kampung Cyber community manager, namely that the development and existence of existing facilities do not have a negative impact on community order. The formation of an attitude of responsibility is always integrated in training and community activities. Not only that, the greetings made between residents also create a responsible attitude in using technology and social media. So that the activeness of citizens is very important in shaping this responsible attitude.

The third is honest. The emergence of the Society 5.0 era, apart from prioritizing technology, also demands a competent and ethical society. Being honest is something that must be taught in digital citizenship education in this Kampung Cyber community. Every citizen must ensure the truth of the news or content posted is important. Communication ethics that can be used in the digital world with the concept of "THINK", that before posting information or news, you must ensure that the information is correct, does not violate the rules, does not offend and disturb others. This needs to be done so as not to cause conflict in the community. The community said that initially they did not care about what they posted, which led to conflict between members.

Next is critical thinking and problem solving. Critical thinking is an ability that must be possessed in the era of Society 5.0 as it is today and is one of the ethics in the digital era. Critical thinking behavior is taught to the Kampung Cyber community through sharing media and the problems faced. This critical thinking ability indirectly trains problem-solving skills. So these two competencies are related to each other. As a village that adopts technology, of course there will be many problems faced, therefore the people there are accustomed to being able to think critically and solve the problems at hand. A critical mindset will make a person critical of the information received. Thus, it will shape ethics in society by being more selective in trusting information. Similar to the previous competency, this critical thinking and problem-solving behavior is internalized to the community through community activities. Apart from that, involving residents in solving community problems also trains in problem solving skills.

The fifth is creativity. Digital citizenship education in Kampung Cyber requires people to be creative in utilizing existing technology. The Kampung Cyber community is given the freedom to make various applications and other things related to technology. This is so as not to limit the abilities possessed by the community. Not infrequently the creativity that is created is used en masse in Kampung Cyber. With the formation of this creativity, it is hoped that it will be able to form a sense of respect for other people's work. Currently the Kampung Cyber community has the 
SiWarga application which is used for the purposes of managing population administration online. This application has received a good response from the community because it is very helpful for the community. Creative things like this are needed in the era of Society 5.0. According to the local community, So far the Kampung Cyber community has always encouraged the creativity of its citizens by holding trainings to create new applications. Next up is equality. Equality material emphasizes the rights of each individual. Every individual has the same right and position in using technology, so that every technology user must respect the existence of other users and respect their rights. This puts more emphasis on the use of social media. So far, people only think about themselves when using social media. As stated by a teenager in the Kampung Cyber community, they do not understand how to treat other users on social media. So the value of equality is given to the community so that they can respect the rights of others by making posts that are not offensive, respecting each other's differences.

Lastly, it's Local Wisdom. As we all know that each region has its own local wisdom. Kampung Cyber Community utilizes existing local wisdom as material and media in shaping digital ethics. As Koko said, even though digital development is getting faster, it doesn't mean we have to abandon existing local wisdom. This could be a fortress for us to avoid the negative impacts of the digital era. This is relevant to the formation of digital ethics which is the focus of digital citizenship education in the Kampung Cyber community. One of the values used comes from the Javanese proverb, namely "Ajining diri saka lathi ajining awak saka tumindak" which means that a person can be judged by his words and deeds. If someone uses technology for negative things it will appear that he is not a good person and vice versa.

One of the uniqueness of digital citizenship education in Cyber Village in shaping community digital ethics is the use of local wisdom as a learning medium. One of them is the use of the Wayang character as a messenger in the mural image. Mural is one of the arts that is often found in Indonesia and is one of local wisdom. The definition of a mural is a large painting made to support architectural space [20]. Murals are made on the walls of large buildings. Murals are often used as an alternative medium for street visual art / street art that serves as a forum to show people's aspirations through paintings with nuances of criticism, information, and as a unifying tool between artists and society. Messages in mural art are conveyed through visual forms which are full of symbols, signs, the code and meaning depicted on these characters. Along with the times, mural art is not only used to decorate spaces and strengthen architectural figures, but the process is to consider and add visual elements related to the message content and the context of the social environment.

Mural art is considered effective in conveying messages to the wider community because a display that has aesthetic value can attract attention. Kampung Cyber is one that uses mural art to convey educational messages. Almost in every corner of the Kampung Cyber community, there is mural art containing educational messages. Here's an example:

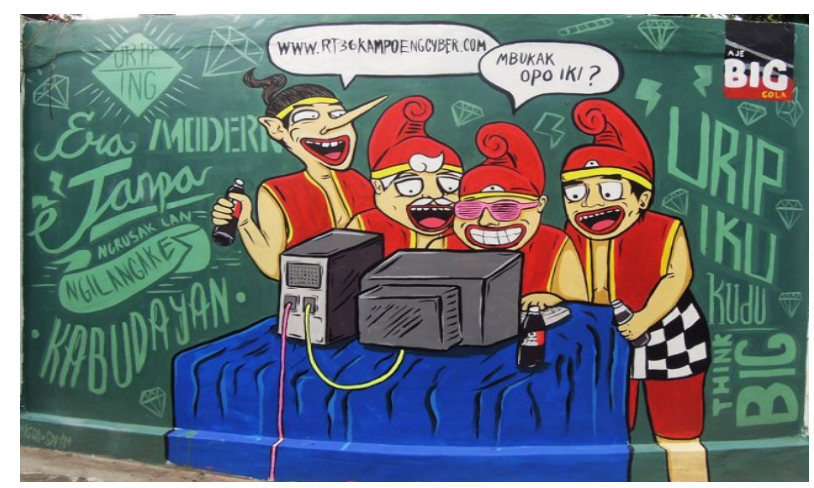

Figure 2. The one example of mural art at Kampng Cyber

The picture above is one of the mural arts taken in one corner of the Kampung Cyber community. In the picture, there are four puppet characters named Punokawan who convey the message that "the modern era must not destroy and eliminate culture and life, we must think big". The message conveyed in the mural means that a person may follow the flow of modernization and technological advances that occur but still maintain their own culture. Included in utilizing technology must be in balance with the environment and one's abilities by upholding existing norms. In other words, in using technology one must adhere to applicable digital ethics. Respecting for the rights of others is the main key in using technology.

If you look deeper, there are a lot of mural arts in the Kampung Cyber community that can be found. Every mural that is made has a message, including digital ethics. This was done by the community manager of Kampung Cyber because the messages conveyed visually were easier to receive than verbally. Many murals convey messages related to digital ethics, such as prohibiting spreading fake news, stopping bullying and so on. It is hoped that the many murals in Kampung Cyber can instill digital ethics in society. Mural art indirectly helps the community in facing the Society 5.0 era which requires synergy between technology and society so that people do not lose their role in the future.

All the basic materials and values above are always carried out in every activity carried out in the Kampung Cyber community. Although there are no specific activities in the formation of digital ethics, the internalization of basic materials and values that is carried out repeatedly in everyday life has brought big changes in society. The existence of the Kampung Cyber community itself is the first step in the implementation of digital citizenship education for the people of Kampung Taman. In addition, the learning process is also different when compared to formal schools. It was said by several residents that the existence of Antonius Sasongko (Koko) was an important 
figure in the formation of digital ethics there. The community views koko as a learning process in itself. What Koko did became their basis for acting, especially in using technology. So if you look at the condition of the people in Kampung Taman, a lot has changed since the existence of the Kampung Cyber community. Now people's lives can be better by utilizing existing technology and they are aware of the importance of ethics in using social media.

So from the above discussion we can discuss that the formation of the Kampung Cyber community is an effort to implement digital citizenship education in society, especially the formation of ethics. If we look at the Kampung Cyber community, the process of forming digital ethics uses a social learning theory model. Social learning theory is also known as observational learning (Modeling) developed by Albert Bandura, so it is a relatively new learning theory. According to Bandura, social learning occurs through imitation and presentation of examples of behavior in the environment (modeling). The application of digital citizenship education in shaping ethics for the people of Kampung Taman adopts this social learning theory. There is the character Atonius Sasongko (Koko) as a role model for the behavior of the people there. As stated by Bandura, People who come into contact with a person regularly limit the types of behavior that will be observed repeatedly and therefore studied with great care [21]. So that the more often people interact with the models they observe, the more carefully they will imitate this behavior. The pattern of behavior shown by a model will determine the Kampung Cyber community in shaping the digital ethics of society. People in the use of technology and social media imitate the behavior of the model they observe, namely Antonius Sasongko (Koko). A big change occurred in the behavior of the people in Kampung Taman after the existence of the Kampung Cyber community, such as reduced post content that creates conflict, public awareness to use technology wisely, respects the existence of other users and the formation of digital ethical competences in society.

Albert Bandura said that the environment also influences the learning process / social modeling. Behavior partly creates environment and environmental consequences, in turn influence behavior. In this two-way causal process, the environment is as influential as the behavior it controls [21]. The Kampung Cyber community strives to create an environment that encourages the formation of digital ethical competences for the community. The existence of strong ties and community participation in Kampung Cyber community activities encourages the successful implementation of digital citizenship education, especially in the formation of ethics. This implies that the social capital in the Kampung Cyber community affects the digital citizenship education process, especially in shaping ethics. Social capital is a series of informal norms that are shared among members of an interrelated community group, which are based on the values of beliefs, norms and social networks [22]. Where digital citizenship education in the Kampung Cyber community begins with the agreement of prevailing norms and mutual trust and citizen involvement which ultimately creates strong bonds in society that encourage the successful formation of ethics there. Until now, the implementation of digital citizenship education in shaping ethics in Kampung Cyber Community has become a role model for other regions. So it's no wonder the existence of the Kampung Cyber community accelerates the digitization process so that it can form ideal and ethical digital citizenship in Society 5.0. So that the existence of the Kampung Cyber community is recognized by the community, academics, and the government.

Viewed from the perspective of civic education, the emergence of the Kampung Cyber community as a forum for education in society is included in the socio-cultural domain. This is in line with what Winataputra expressed that Civics is a scientific structure that has a systemic paradigm in which there are three domains [23]. First, the academic realm, which is a scientific study program implemented by the Civics academic community using scientific research approaches and methods to solve conceptual and operational problems. Second, the curricular realm, where the concepts and practices of Civics in the world of formal and non-formal education. Third, the socio-cultural realm, the concept and practice of Citizenship Education as a vehicle for self-actualization of citizens in society. The three of them have structural and functional relationships that are bound by the civic virtues and civic culture which include civic knowledge, civic disposition, civic skills, civic trust, civic commitment, and civic competence.

Citizenship education as a socio-cultural domain is a citizenship movement that acts as a vehicle for self-actualization of citizens both individually and in groups according to their rights, obligations and socio-cultural context through active and responsible participation. So that the Kampung Cyber community as a subject in this study is a form of actualization of the social and cultural community movement which provides space for the residents of Kampung Taman to learn together to help create a community 5. 0 , namely people who take advantage of sophistication. information technology wisely and ethically. The Kampung Cyber community is present in the community to build digital ethics that every technology user must have. So that the existence of the Kampung Cyber community is important for the development of civic education, especially in the socio-cultural domain.

\section{Conclusions}

Digital citizenship education is needed in the Society 5.0 era. Education has an important role in shaping individuals to become good and ethical digital citizens. The good and 
ethical digital citizens can be seen by three aspects. They know the values and norms in using technology appropriately and effectively, having digital awareness, and understanding digital rights and responsibility.

From this research, the researchers found that the emergence of a digital community such as Kampung Cyber proves that forming a digital ethic does not have to be through formal education in schools. Communities that were formed on community initiatives turned out to be more effective in shaping digital ethics in the Society 5.0 era. Every existing norms become a bulwark from deviance. The continuous internalization of values is able to form new habits in using technology and the internet. The existence of key figures who become role models for the community becomes their benchmark in using technology and the internet. So here the social capital in the Kampung Cyber community has a big influence in the formation of etuka there. So do not be surprised if the Kampung Cyber community can be a role model in implementing digital citizenship education in society, especially in the formation of ethics. This is relevant to the principles of the Society 5.0 era, namely the balance between environment and technology. The emergence of the Kampung Cyber community can develop civic education, especially in the socio-cultural realm. The existence of key figures who become role models for the community becomes their benchmark in using technology and the internet. So here the social capital in the Kampung Cyber community has a big influence in the formation of etuka there. So do not be surprised if the Kampung Cyber community can be a role model in implementing digital citizenship education in society, especially in the formation of ethics. This is relevant to the principles of the Society 5.0 era, namely the balance between environment and technology. The emergence of the Kampung Cyber community can develop civic education, especially in the socio-cultural domain.

\section{REFERENCES}

[1] Skobelev, P., \& Borovik, Y. S., On The Way From Industry 4.0 To Industry 5.0: From Digital Manufacturing To Digital Society, International Scientific Research Journal «Industri4.0», Vol. 2, No.6, pp. 307- 311, 2017.

[2] Özdemir. V, Birth of Industry 5.0: Making Sense Of Big Data With Artificial Intelligence "The Internet Of Things" And Next-Generation Technology Policy. A Journal of Integrative Biology, Vol. 22, No. 1, pp. 65-76, 2018.

[3] Rokhmah, N. I., The Role of Mathematicians in the Industrial Revolution Era 4.0 Relevant Technology Becomes an Integral Part of the Curriculum, 2019.

[4] Faruqi, U. A. Future Service in Industry 5.0: Survey Paper, Journal Sistem Cerdas, Vol. 2, No. 1, pp 67 - 79, 2019.

[5] Team APJII, Survei Pengguna Internet APJII 2019-Q2 2020,
Buletin APJII Jakarta, Edition 74, pp.1-2, 2020.

[6] Patroli Siber, Statistik Jumlah laporan Polisi yang di buat masyarakat, Retrieved from https://patrolisiber.id/statistic.

[7] Mossberger, Karen \& Caroline J Tolbert, Digital Citizenship: The Internet, Society, and Participation, MIT Press, Cambridge, 2008.

[8] Moonsun Choi, A Concept Analysis of Digital Citizenship for Democratic Citizenship Education in the Internet Age, Theory \& Research in Social Education, Vol 44, No 4, pp 565-607, 2016.

[9] Nasrullah, Rully, Theory and Research (Cyber Medi), Kencana, Jakarta, 2014.

[10] Team Education APEID-ICT, Fostering Digital Citizenship through Safe and Responsible Use ICT, UNESCO Bangkok, 2015.

[11] Tolbert, Charles M, Minding Our Own Business: Local Retail Establishments and the Future of Southern Civic Communit, Oxford University Press, Social Forces, Vol. 83, No. 4, pp. 1309-1328, 2005.

[12] Sugiono, Metode Penelitian Pendidikan:Pendekatan Kuantitatif, Kualitatif, dan R\&D, Alfabeta, Bandung, 2015.

[13] Governor's Regulation DIY No. 42 Tahun 2006 About Blueprint Jogja Cyber Province.

[14] Lee R. Matthew, Shaun A. Thomas, Civic Community, Population Change, and Violent Crime in Rural Communities, Sage Publications, Journal of Research in Crime and Delinquency, Vol. 47, No. 1, pp. 118-147, 2010.

[15] Tredinnick, Luke, Digital Information Culture: The Individual and Society In The Digital Age, Oxford, New Delhi, 2008.

[16] Muhammad Badri, Pembangunan Pedesaan Bernasis Teknologi Informasi dan Komunikasi (Studi Gerakan Desa Membangun), Jurnal Risalah, Vol 27, No. 2, pp. 62-73, 2016.

[17] Ribble Mike S, Bailey Gerald D., Ross Tweed W., Digital Citizenship Addressing Appropriate Technology Behavior, Learning and Leading Technology. Vol. 32, No. 1, pp. 6-9, 2004.

[18] Kadir Abdul, Introduction to Information Systems, Andi, Yogyakarta, 2003.

[19] Santoso, Slamet, Teori-Teori Psikologi Sosial (Social Psychological Theories), Refika Aditama, Bandung, 2010.

[20] Susanto, Mikke, Diksi Rupa. Kanisius, Yogyakarta, 2002.

[21] Bandura, Albert, Social Learning Theory, General Learning Press, New York, 1971.

[22] Fukuyama, F, Trust: Kebijakan Sosial dan Penciptaan Kemakmuran (Terjemahan), Qalam, Yogyakarta, 2002.

[23] Winataputra, Udin S., Jatidiri Pendidikan Kewarganegaraan Sebagai Wahana Sistematik Pendidikan Demokrasi, Bandung, 2001.

[24] Richardson, Janice \& Elizabeth Milovidov, Digital Citizenship Education Handbook, Council of Europe Publishing, Europe, 2019. 